\title{
The Effects of Economic Crisis on Health: An Overview of the South Korean Case*
}

\author{
JUNG SUN KIM



\begin{abstract}
This articte txamines the social and individual implication of the ritum

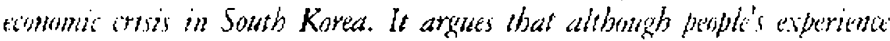
with whmmic wivir may differ contiderably depending on a warierj of

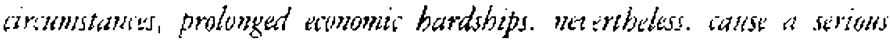

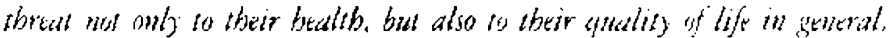

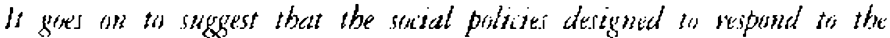

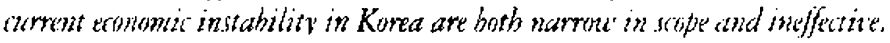
This artile ioncludes with a recommendation of stme neiessing fatori which mast be considered in formulating a long-bern fitwe pintio. phating special amplasis son the reform of social semites.
\end{abstract}

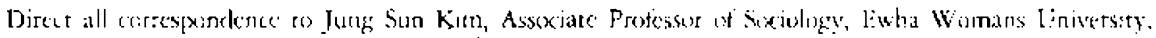

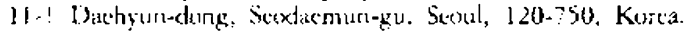




\section{IN"IRODUCIION}

7 he 1997 economic crisis along with the International Monetary Fund (IMr) bailont 1 fund that soon followed, have been responsible for much of the social instability found today in Korca. Although on the surface, the crisis appeared to be a financial one in nature, it was, in facr, a crisis that challenged the very fabric of Korean society. The profound intluence the crisis has had and still has on Koreans is illustrated dearly by some of the economic figures presented by the National Staristical Office (NSO). As of February 1999, more than 10,000 firms have filed for bankruptcy and the number of unemployed due to financial and corporate restructuring have reached 1,078,000 persons, meaning that 8.7 percent of the workforce is unemployed. Even with the optimistic estimations of a two percent economic growth in 199\%, the unemployment rate is expected to climb for some time to come. Nor only has the unemploynent kevel experienced a serious rise, bur the length of the unemployment perioxd has alsu increased. In 1998, the average length of unemployment was between four and five months. In 1999, however, it extended to approximately six to seven months. Furthermore, the percent age of long-term unemployment for more than one year is experted to increase from 1.2 percent in 1998 to 7.1 percent it 1999 (NSO 1998).

The social unrest deriving from such an economic crisis surfaces in various forms. An increasing crime rate, widening disparity between the poor and the rich, and intensifying conflicts of interest between business and labor are some of the major identifjable social problems. The government policies designed to remedy problems such as social unrest are mostly directed at economic issues. Although it may be possible to address these problems by directly tackling the economy and thereby eliminating its side effects, the nature of social unrest experienced by Korta is such that short-term cconomic policies will tail to adequately and sufficiently decal with the depth and scopx: of the crisis. The deterioration of the quality of life for Koreans since the cconomic crisis becomes a major problem in a country where social policies, or social safecy nets, are inakequate to say the least.

In light of the state's historically strong emphasis on "growth first" policies, the govcrnment can not be expected to sufficiently allocate its scarce resources to welfare policies to create an effecrive and meaningful social safety net. As shown in Table I, the share of sorial development-related expenditure is particularly small. The Korean governmenc has, thus far, allocated less than cen percent of its budget to welfare services. Duc to the small percentage of budget allocated to welfare, the state has to prioritize welfare services - medical care protection, peosion for those who are able and willing to join (for example, government employees or workers in big firms), state support for ehe handicapped, the poor and the old, and housing-in order. 'lhe result of this policy is summarized in the outline of the scxial security system in Kurea in Table 2. There have been virtually no social programs for those who need it most. 






Source: Sê, liygs.

TrBLE 2. OMITLINE OF THE SOCIAL SECLRITY SYSTFM IN KORFA, 1998

\begin{tabular}{|c|c|c|}
\hline Social Security Program & When Commenced & Coverage (\%) \\
\hline 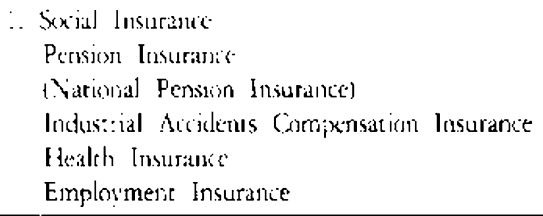 & $\begin{array}{l}1960) \\
1989) \\
19(1- \\
107 \\
1995\end{array}$ & 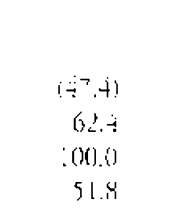 \\
\hline I. Pualic Assistinet & 196: & $3 . \vdots$ \\
\hline  & $190:$ & \\
\hline 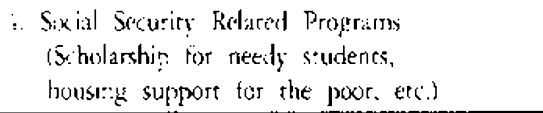 & $195^{\circ}$ & - \\
\hline
\end{tabular}

Source: Pascha and Kwion, 1908

A limired amoune of budget also requires the dependency of social welfare services on the private sector. Although virtually the entire Korean population is covered either by the compulsory National Health Insurance or by Medicaid, 'Table 3 shows that it is mostly funded by private sources. Under the current systenn, 75 percent of physicians and hospitals are also in the private sector, as shown in 'Table 4. They are reimbursed for their services by third parcies such as Heatth Insurance Societies, and are supplemented by the patient's co-payments. The reimbursing schesue, called fee-for-serviceschedule, sets a fixed point for each medical scrvice performed, and providers of medical services are then reimbursed in proportion to the sum of the total points. It has been generally argued that the schedule tying points to the fee is sct excessively low so that physicians sumetimes over-treat (provide unnecessary but motc profitable tratment) patitns with low quality service. 


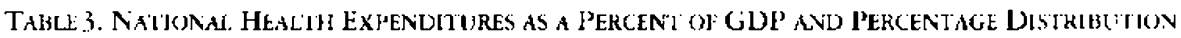

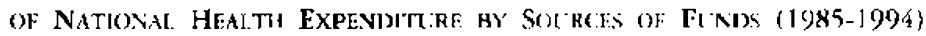

\begin{tabular}{|c|c|c|c|c|c|c|c|c|c|c|}
\hline \multirow{3}{*}{ Year } & \multirow{3}{*}{$\begin{array}{l}\text { Percent } \\
\text { Of GDP }\end{array}$} & \multicolumn{8}{|c|}{ Sources of funds } & \multirow{3}{*}{ Total } \\
\hline & & \multicolumn{4}{|c|}{ Public } & \multicolumn{4}{|c|}{ Private } & \\
\hline & & (invit & SHI & Wl & Total & OOP & Pl & Others & Total & \\
\hline 1985 & +65 & 8.6 & 16.6 & 2.2 & 27.4 & 550 & 4.5 & 13.1 & -2.6 & $100 . i$ \\
\hline$: 986$ & $4 \div 5$ & 110.0 & 14.7 & 2.3 & 27.0 & 56.7 & 4.6 & 11.7 & -3.0 & 100,0 \\
\hline 1487 & (1.2) & 9.3 & 15.2 & 2.2 & 26.7 & 57.7 & $-i .8$ & 10.8 & 73.3 & li10.0 \\
\hline $198: 4$ & +46 & 10.2 & 164 & 2.1 & 28.7 & 35.2 & 50 & 11.1 & 1.3 & $100 . i$ \\
\hline 1989 &.$i .9 i$ & 10.4 & $16 \%$ & 1.8 & 29.1 & $56 ?$ & 5.2 & 4.0 & -0.9 & 100.6 \\
\hline isy & $3.0^{\circ}$ & 11.3 & |り: : & 1.2 & 32.9 & 53.9 & +.3 & 89 & $6 ? .1$ & 1000 \\
\hline :101 & (.) : & 118 & 16.5 & 1.7 & 30.0 & 57.1 &.$+ ?$ & 8.2 & 70.0 & 000.0 \\
\hline $140 ?$ & $5 ; ?$ & 10.5 & 16.9 & 20 & 29.4 & $55 . \%$ & i. 5 & $10 \%$ & 70.6 & 1000 \\
\hline 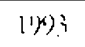 & 5.37 & 10.1 & 17.1 & 1.6 & 28.8 & 56.2 & 5.0 & 10.0 & -1.2 & 100.0 \\
\hline 190. & 5.34 & 9.6 & 17.4 & 1.5 & 28.5 & $5 \vdots 5$ & 5.1 & 12.7 & -1.5 & 1000 \\
\hline \multicolumn{11}{|l|}{ Nose: } \\
\hline
\end{tabular}

Source KIHM, 19ux.

Tabie 4. Nlimber of Hospital. Bfins in Plibilk; ani) Phivate Sfictor (1985-1995)

\begin{tabular}{|c|c|c|c|}
\hline Sectur & 1985 & 1990 & 1995 \\
\hline Public & $\{7,385\{25.0\}$ & $\because 10(8,26,6)$ & $35,2\{1(25.1)$ \\
\hline Prisate & $52,16 \times(75.0)$ & $686580.60)$ & $105,38(x \div-1.9)$ \\
\hline Tural & $(2), 553(100.0)$ & $92 \div 2(x<1)$ & $40.6210: 10000$ \\
\hline
\end{tabular}

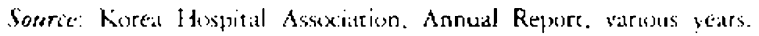

Although the shift in emphasis from economic growth to a higher quality of life has become a critical issue in recent years, the state's efforts in welfarc development have nor improved much since the conomic crisis occured in 1997. Individuals and farmilies have been largely responsible for their own quality of life. This fact presents an extremely daunting prospect in overcoming the negative impact that the crisis has had on the mental and physical health of the Korean people.

Infortunately, there has not yet been a systematic analysis of the truc effects of economic crisis on the individual, community, and sociery as a whole in Korea. The Lnited States and Europe, un the other hand, have managed to accumulate rescarch that sheds light on the relationship between economic recession and quality of life. Among the voluminous worldwide literature on economic hardship and health, there has been a general consensus that a large majority of the unemployed sutfer from 
physical and psychological impairment. The Great Depression and the early 1980's recessiun both in che United States and in Western Luropean countries stimulated extersive rescarch on the effects of unemploynent (Fryer and Payne 1986; Siconson 1987: Liem and Rayman 1982). Compared to Gircil Depression literature where gualitalrive case studies were the predominant mode of analysis, the more recent works tend to rely on statistical analysis of individual dara (Jahoda 1988).

Thesc studies on economic recession and health can be categorized into two different research approaches. One is the traditional social and psychological approach which relies on interiews and questionnaires as the main source of research. It can be referred to as the micre-study of economic recession and health, for it focuses on the personal expericnees of unemployed individuals (Jahoda 1988; Iversen and Sabrex 1988; Liem and Licm 1988; Dowley and (atalano 1988). Another research approach on economic recession and health is the soxial epsilemiological approach, which uses aggregate data to analyze the effeces of large-scale economic changes on the yuality of life of the whole: population. A well acknowledged work at this level is that of Brenner's, who raises the question of how mass unemployment is related to various indicators of social pathology: (Brenter 1987a,b,c).

This study aims to evaluate whether the common results of the past studies mentioned above can be tound in today's Korean socicty through the currently avalable figures and sexial problems afflicting quality of life and the status of health. Considering that Korea has not expertenced a severe cconomic recession let alone a crisis since it began its development efforts in the 1960), studies and data on uncmplowmene and its relation to health are scarce. Another reason behind this scarcity is that the effects of economic recession on health require years to emerge, particularly in the form of aggregate data, and in the case of Korea, it has been under two years since the government officially requested the MMF bailout fund. However, there have been hundreds of casts rejortcal everyday indicating possible negative influences of the economic crisis on the health of the people. Thus, the need for discussion of the relationship between economic hardship) and health in order to determine the soxial implications of economic crisis is urgent.

In the fullowing section, social changes in people's daly live's since the economic crisis that may acgatively affect their health status will first be examined. Then, the effects of coonomic crisis on health will be cxplored in both demand and supply dimensions of health care. As a means of investigating che demand for health (are, availible macro) data and micro-level studies on social psychology will bo reviewed. Also, the way in which the health care system is evolving to meet this thallenge in demand and the sccial implicarions of such a process for people's healels will be discissed. Duc to the nature and limiation of the data ayalable so far, this study eloes not attempr ti make a definate conclusion about the negative effects of the economic crisis on health. It will rather toxus un various implications of the social and health problems that have been cmerging from, and the harmful social offects of, the economic crisis, linally, the paper will critically scrutinize the current policies being inplemented, and suggest possible 
policies necessary co enhance the quality of life in the midst of economic crisis.

\section{ECONUMIC CRISIS AND SOCIAL CHANGES}

\section{Unemployment and Living Conditions}

The most prominent change in Kotean society as a result of the economic crisis is rising unemployment. Unlike Western countries that have experienced regular and cyclical economic recessions, Korea has experienced continual economic growth until the recent crisis. 'lhus, the sudden and rapid increase in unemployment has become a major social problem as shown in Figures 1 and 2. Examining the uncmployment situation in detail, statistics show that in the past year the tate of unemploymont has quadrupled from a pre-IMF rate of 2.3 percent, and such a trend is expected to concinue for some time to come. Unemployment in Korea is due to a shrinking demand in the labor market and massive layoffs as a result of restnicturing efforts in the business sector. Of those unemployed for a period of less than a year, 43.7 percent have responded deceriorating business performance to be the reason behind their loss of work. Other reasons include carly rerircment, honorary retirement and layoffs for 16.8 percent, and shuedown or closure of workplace for 12.6 percent, all of which are direct consequences of IMIFguided business sector reform (Yoo 1998). In addition, the length of the unemployment period has increased. Those unemployed for a period of longer than six monchs is approximately 24.1 percent this year. Uncmployment is expected to quickly spread from the less educated and unskilled to the highly educated and skilled. The



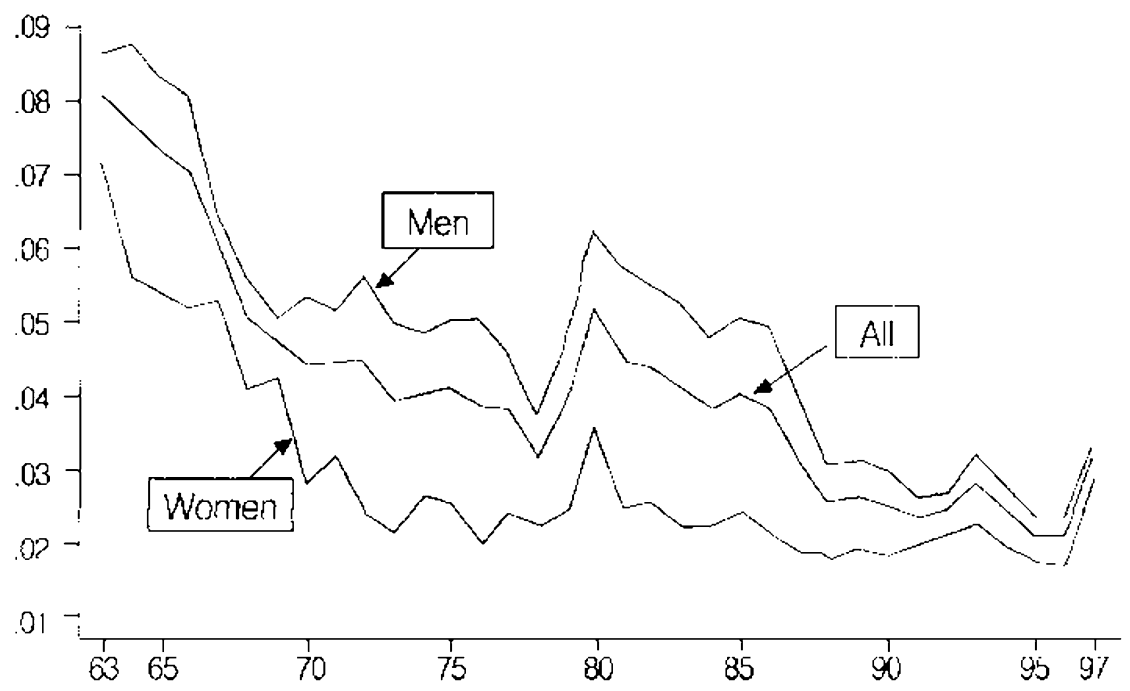

Source: Lec and Kim. 1998, 23. 
FICISKE 2. RECFN"] DEVEIOPME.NT IN FMPIOMMFN'J IN KÓOREA

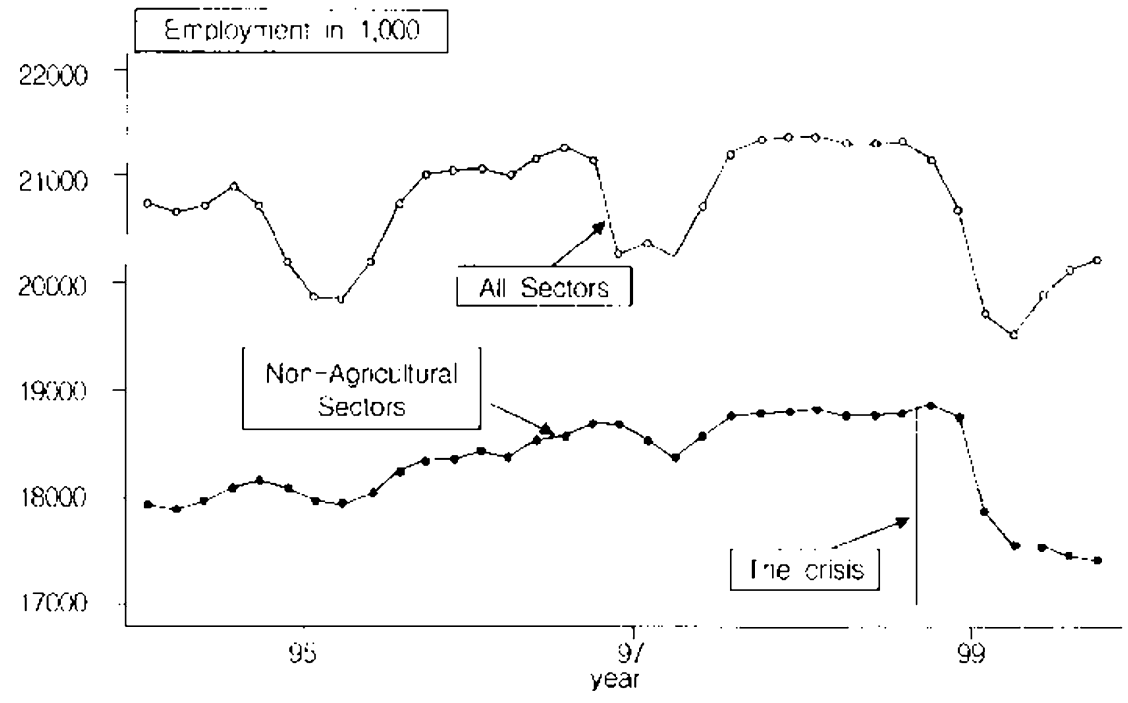

Simmer : Jee and Kim, 19\%8, 1.j.

labor market is experiencing a situation where the latter is undergoing downward mobility in work, squeezing the former out of the job market. Hence, a greater increase in the number of unemployed of the less educated and unskilled workforce is also expected (Korca Iabor Insticute 1998).

This situation decreases the living standards of the overall pxppulation in general, but thase who are most affected are from the low-income (lass. According to the National Statistical Office, houschold earnings in the lowest 20 percent income strata have decreased by 14.9 percent, while those of the highest 20 percent income strata have slightly increased by 2.4 percent, as presented in lable 5 . Due to a decrease in income, houschold consumption has also significanty reduced an average of 16.8 percent for the low incume group. The average consumption level of the middle class has experienced the stapest decline with 18.9 percent (NSO 1998b).

Tabl.F 5. Changes IN CRBaN Hoh:sehold INCOME

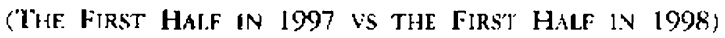

\begin{tabular}{|c|c|c|}
\hline Household's Income Quintile & Total Incurnt & Iabyx Incones. \\
\hline $1^{\prime \prime}$ quint: $]_{t}$ & $\cdot 11 ; j$ & -13.0 \\
\hline$?^{\cdots 1}$ quirtile & -8.8 & -56 \\
\hline$i^{* 1}$ cuintile & -6.9 & -4.2 \\
\hline$f^{! !}$:inistolc: & $-5,5$ & -2.2 \\
\hline $5^{\text {:h }}$ quintile. & 2.3 & -0.6 \\
\hline
\end{tabular}

Soure: Nit:unsi Scarciscical office, 19u\&b). 
Another health-related factor that has experienced deterioration is the quality of the living enviromment. A $19 x) 8$ study of residents of Seoul (ity and the suburban arcas showed a continual risc in the ratio of home owners, an increase in living space pert family, and an improvement in living facilities in pre-IMF Korea. But those who have moved residences post-IMF have generally relocated to less desirable areas. The numbers of homeowners has decreased from 25.8 to 18.9 percent, living space per family from 19.2 to 18.3 square feet, while one room family occupants have increased from 10.8 percent to 12.9 percent (Cho 1998).

In relation to living conditions, an emerging problem that has bxen identified is an increase in the number of honeless. According to past western studies on the relation Ix-tween the living environment and health, compared to an average person, a homoless individual is 2.5 rimes more likely to make hospital visits and is 3 times more prone to illnesses such as chronic respiratory disease. Also, the prevalence of asthma among homeless children is twice that of average children. These health indicarors suggest that a poor living environment has a direct negative effect on health (Breakey et al. 1989; Wright 1990; Coldbladi 1990).

In light of the studies mencioned above, the fact that the type of housing in Korea is undergoing a shift from ownership to renting, monthly renting, and homelessness. suggests the possibility of future increase not only in respiratory and infecrious diseases in the future, but negarive health consequences in general. The number of hemeless in Korea has increased from 1,000 in February 1998 to 6,000 later that same year. Of this six thousand, 7I percent are so-called "IMF homeless." Approximately 70 percent of the IMIF homeless had daily employment, confirming again that the biggest victim of the economic crisis is the low incorne class (D. Kim 1998).

\section{Disintegration of Families}

Most studics that examine the relationship between economic crisis and bealth on an individual level have shown that social nerworks play a very important role in the relationship as a mediating variable. Particularly in a country where the government lacks experience managing social problems deriving irom economic downturn, and where institucional safety nets remain undeveloped, the sixial network of family and friends can become a vital source of alleviation. Western studies show a correlation between unemployment and divorce rates, and suggest that unemploynent has a negative influence on the husband-wife and parent-child relacionship, giving rise to various forms of stress, conlict, and tersion (McLoyd 1920; Molnar et al. 1990; South 1985). Therefore, unemployment does not mercly lcad to financial difficulties, but it also increases the possibility of a change in family dynamic. On the other hand, some srudies on the Great Depression suggest that in times of crisis, families form a tighter bond, becoming a major facilitator in overcoming hardship. Such contrasting outcomes in the studies indicate that depending on different variables, the results vary considerably (Moen 1979), 1983).

The avalable data tend to support the former lypothesis. According to one such 
study, mermployment of the head of the farmily (or the breadwinner) negatively intluences a child's emotional condition. The sample size for this rescarch consisted of 336 students including 112 children of unemployed families. The ration of the level of cmotional instability of children from unemployed families to employed was greater. The srudy shows in detail that parental artitude strongly correlates with the child's emocional state. If hoth parents are seen to demonstrate negative attitudes such as disintercst, defensiveness, and aggression, the children showed a high level of emotional instability. whils children of those parents whose atcitude remained relatively unctanged experienced relatively less instability. This pertains not only to parent-child relationships, but to husband-wite and other farrily relations as well (Le et al. 1998).

Nineteen ninety eight reports from the Korea Leyal Airl Conter for Family Relations show that families have been disintegrating at an increasing pace. Ot the total number of cases consulted in 1998, 60.7 percent was divorecrelated, an increase from 51.1 percent the previuus ycar. Among the reasuns for divorce, 23.6 percent of the cases were related to financial conflict, 14.5 percent to debt, I I percent to gambling, and 8.8 percent to ecomomic incomperency, all of which are closely linked to financial instability (Lee 1998). This suggests that in Kurea, the tamily unit cannot fulfill its positive role as mediator in the face of economic crisis. This leads to the conclusion that without strong social safety nets, Koreans will experionce greatcr health risks.

The discussions and data provided above are by no means extensive, but it does sufficiently indicate to what extent and in what ways people's daily lives are being threatened by the economic crisis. We can then probx deeper and examine how these social changes affect the health of an individual and his fanily. The section below illustrates that there has been an increase in demand for, but a decrease in the supply of health care since the economic downeurn.

\section{DEMAND DIMENSION OF HEALIH CARE}

\section{Physical Health Problems}

Previous macro-level scudies on the relationship between economic crisis and lealth have reported that an increase in unemployment due to economic risis leads to an increase in mortality risk as a result of increases in carcliovascular and renal diseases, liver cirrhosis, as well as an increase in the infane mortality rate. Such studies examine the relation of economic recession to health by using a longitudinal approach in order to analyze the changes in people's state of health after experiencing an conomic recession. Accotding to such studies, the time lag for negarive effects to appear is on average six years. In the initial phase of financial difficuley, the death rate among the poor and the suicide rate increase, but there is a time lag of five to six ycars for such an effect to emerge for the general population. Also, the relationship between the rate of unemployment and death showed a curve that reached its peak at two to three years and shows a cimc lag of an average of six years (Brconer 1987a, b, c). 
The necessity of a time lag to determine the effects of an economic crisis on health indicates that it is premature to draw a definite cunclusion on the negative effects of the Korean econornic crisis on the health of its citizens. Also, due to the scarcity of systematic reseatch on the relationship between economic crisis and healeh, it is alifficult to determine whether hypotheses of cxisting Western research can also he applied to the Korean experience. The following studies thus far conducted on Korea, nevertheless, imply that economic crisis docs threaten the well-being of its population.

First, the death rate due to a stroke or heart attack in the first half of 1998 has risen 16 percent from the year before, and the rate of increast has been faster than before (Miniscry of Health and Welfare 1998). According to figures provicled by a university hospital, the 21 patients were admitred to emorgency tooms for acute myocardial infarction becwoce January and March 1998, twice that of last year. There has also been an increase in the number of patients under the age of 45 , from one to ten parients, in a year (D. Kim 1998).

It appears the usc of medical services by the middle-age population, between 30 to 55 years of age, and the elderly has relatively increased since the conomic crisis. This is actributed to an increase in various diseases related to bloxd pressure and the heart, illnesses triggered by stress. Figure 3 illustrates the changes in the ratio of age groups making use of medical insurance in 1990, 1991 and 1998. 'The figures demonstrate that while yourh make increasingly less use of metical services, the trend is opposite for the older population. What is significant, however, is drastic increase in the use of medical facilities by the middle-age population in 1998 compared to both pre-crisis years of 1900 and 1994 .

figlre 3. Changes in the Ratio or age Grolps making: USI: OF MEDICAL INST RAYYC:

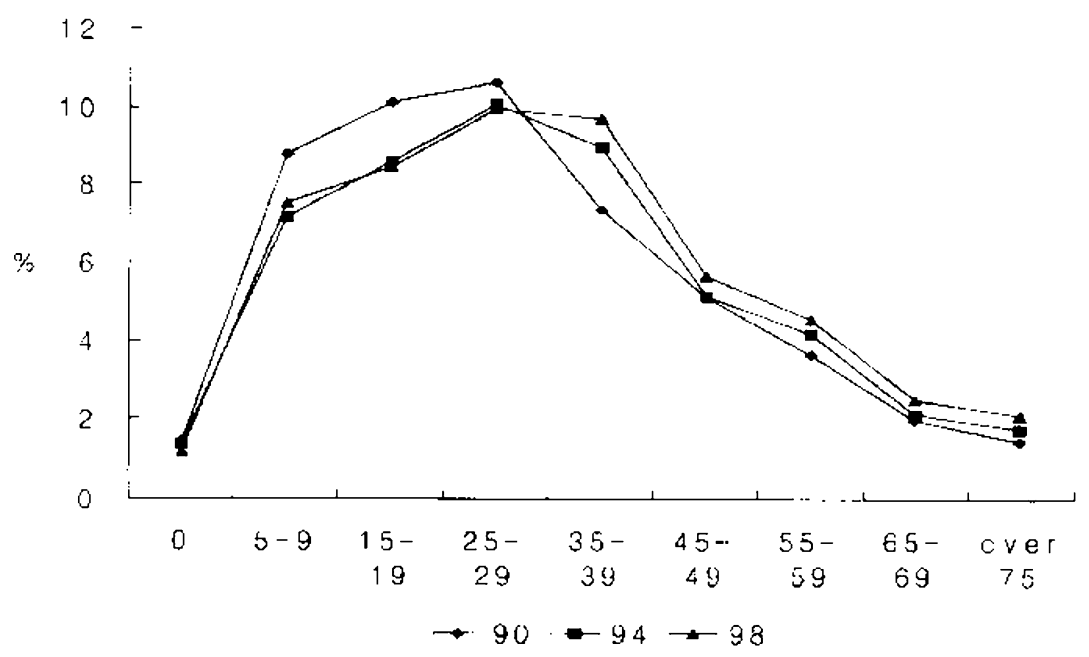

Sonte: Stuin at ai., 1949. 
'There has also been a report of a noticeable incrcast in patients with hepatitis type $A$ as a result of detcriorating sanitary conditions in their living surroundings, which is again related to conomic difficulties. According to rescarch conducted by the Korean Ijver Asscciation on patients with hepatitis cype $A$ in 85 major hospitals throughout Korea from July 1996 to June 1998 , the number of hepatitis patiencs increased from an average of $\mathrm{IA}$ in November 1997 to 64 patients in December 1997, an incresse of 4.5 times. This trend steadily rose in 1998 with 98 paticnts in January, 136 patients in Febnary, 155 paticules in March, 217 patients in April and 332 patients in May (Choi 1998). Since hepatitis $A$ is prevalent in less developed countries where unsanitary living conditions make it possible for hepatitis $A$ to spread and thrive, we can derive that deteriorating living conditions is a serious concern as the cconomy worsens.

Ar the same time in the district of Seoul, cxcurrences of cuberculosis that previously showed a decrease from 2,178 cases in 1995 to 1,816 cases in 1947 , exhibited a reverse effect with an increase of 2,071 cases in November 1998 , actually excerding the number threc years before (MOHW 1998). According to a study conducted by the Korean Asscxiation of Tuberculosis in May 1998, of the 2,432 homeless 9.5 percent, or 231 people. were diagnosed with tuberculosis (Cho 1998). Although the statistics cited above were from research conducted within a short-rerm time framework, it illustrates the fact that the economic crisis has begun to seriously affect the health of Korean people.

One of the most critical health problems produced by cconomic crisis has been the sale of bodily organs. The process involved in organ transplantation in Korea has gencrally been through informal channels, and has yet to be institutionalized into a legal procedure or systematic management. There are only a handful of hospitals with centers for organ transplant, where contacts between the donors and receivers are atranged and operations take place. With the recent economic crisis, the number of organ donors has suddenly increased. The number of organ consultations at a major hospital increased to threc to five cases from half to one case. A majority of those consulted were predominantly male and in their forties during the pre-oconomic crisis. Recently, however, the demographics have broadened to include those in their thirties and forcies and an increase in the number of females (Cho 1998). This indicates that there are an increasing number of desperate perple who must resort to selling their bodily organs for survival. Withour proper legal procedures and management guiding the organ transplantation process, the situation becomes more alarming. In light of this new problem, the special comnittee of Health and Welfare in Congress has just recently drafted a bill that acknowledges brain dearth and permits organ transplantation of a person over 16 years of age. If passed in the Parliament, it will be implemented in January 2000.

\section{Mental Ilealth Problems}

It is too early to come to a definite conclusion on the effects of economic crisis on a population's mental and physical well-bcing using macro-level data. The effects on the social psychological well-being of an individual, however, can lx decemined with greater accuracy by examining the avalable survey responses, In this section. we will 
review the findings of such studies in an attempt (s) urederstand the depth of negative effects of the conomic crisis on the physical and mental health of the Kurean population.

According to a survey study on the physical and mental health of 447 uncmployet. 24.1 percent responded as having had to make a visit to the hospital for a new ailments after losing work (Le and Lee 1998). The findings report that the rate of new ailment increased for groups that experienced unemployment for a prilunged perioxd of over a year. Although the question of whether their newfound illness is a direct cause of loss of work dows not go undrallenged, most illnesses were found to be related to stress resulting from uncmployment, proving indirect correlation. Most of the respondenes were suffering from ar least one physical malady since the loss of work, and anong them, severe headaches and insomnia were the must common complaints with 74.3 percent and 56.8 percent, respectively. Asthenia and changes in weight have also been cited with 21 percent and 20.6 percent, respectively. 'They also found that approximately 34.1 percent of the unemployed considered sucide, 51.3 percent among those unemployed less than a year. The statistics reveal that in a country whers job security has lxeen relatively stable throughout its economic growth, loss of work becomes a teison for tremendous shock. These figures give support to western findings that state that negar.jve psychological conditions, such as suicide contemplation, are highest immediarely after an economic recession sets in. Also, from examining the responses of 76.1 percent of the unemployed who said they felt a strong urge to blame someone for their financial difficulties, we can speculate that for Koreans, unemployment is considered to be an unexpected and very stressful life event. It has long bxen acknowledged that major changes in life, such as unemployment or the death of a spousc, act as a "stressor," thereby affecting the immune system and hormone secretion, which uleimately harms an individual's physical well-being.

One of the most frequent ways in which people cope with stress aggravated by economic crisis, and in the process abuse their health, is through drinking-related activities. There ate two contrasting arguments in prior studies on economic crisis and drinking habits. One is that unemployment due to an cconomic crisis decreases the porential to consume alcohol (Seeman 1992; Hammer 1991). The other argument is that consumption of alcohol increases due to stress and with it, brecds various social problems (Brenner 1975; Catalano et al. 1993). Hence, the former study suggests that there is no significant relationship between unemployment and alcohol consunption. Ihe latter detecrs a positive relationship between the rise of unemployment and rises in alcohol sales, medical facility use due co alcohol abuse, alcohol related crimes and finally, death due to liver disease. In Korea's case there is insufficient data, as of yet, to draw the conclusion that economic crisis leads to alcohol abuse. There are, however, isolated instances that give support to the former study. For cxample, the main cause of the rise in family disintegration since the economic crisis was attributed to drinking habits and physical abuse by the unemployed member of the farmily, in moss cases the father (Lee 1998). Also, according to the Prosecutors Investigation Otfice, the number of those prosccuced from drinking-and-driving cascs approximately quadrupled in 1998 (Chesurallbo 1999). Since Korea's conomic recession and restructuring efforts are 
expected to cause a continual rise in uncmployment, we can expect to lace various problems in people's health in the foreseeable future:

However, many studies show that rather than havitg a direct effect on rhe physical and psychological well-being of an individual, the negative impact of economic crisis appears through mediating variables. Taking into account the report by Rabkin and Streuning (1976) which states that a direct correlation of independent variables to stress-i.c., economic hardships-and health is less thran ten percent, there is a fair chance that the relationship between economic crisis and health results from an inreraction between several variables.

In Korea, it has been suggested that individual attribues such as sex and personality, as well as secial attributes such as social support and access to welfare systems, are variables that alleviate or accentuate the harmful effects of stress caused by an economic crisis. The two studies by Kim and Noh (1998) and Whang et al. (1998) highlight that social relationships such as family and friends work as influential variables to economic stress. Although on many ociasions, one can seck understanding and assistance in social relationships, an individual subject to an increasingly high level of comonic stress was seen to fed constantly judged and criticized by the very same relationships. This funding suggests that as an conomic crisis continues, it diminishes the mediating role of soxial networks and reduces social sympathy. In Kurea, where family takes on the role of a social safety net, conflicts in such relarions causc an individual to lose the resources needed to overcome the economic crisis, ultirnately making himself more vulnerable to it.

\section{SUPPLY DIMENSION OF HEALTH CARE}

The nezative implications an economic crisis has on the well-being of the population as explained in the previous section suggests the need for public and private institucions to provide necessary assistance to secure people's quality of life. One thing that must. be examined is whether or not social resources for assistance are being adequately and sufficienty provided for. In this section, problems in social and medical resource distribution will be pointed out and some of the social changes that have a ncgative influence on people's health will be discussed in the next section.

\section{Health Care Spending}

The crisis becomes dire when we examine how much individuals and the guvernmente are spending to cope with the aforementioned health problems. Since the economic rrisis, the average houschold expendicure on health has decreased by 17 percent while govermment expendirure on health care declincd approximately 7.1 percene (NSO 1498b). While this decline in health spending is relatively low compared to the decline in overall government expenditure, the demand for medical care has increised at a rapid rate, signaling grave consecpences. According to the National Healeh Insurance Corporation 
(NHIC) and as can be seen in Figure 4, the rate of increase in medical consultation fees and the number of consultations was at its peak in 1995, but drastically tell, along with the decline in GDP, post-crisis.

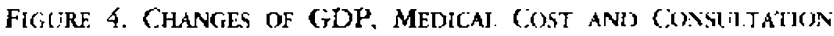

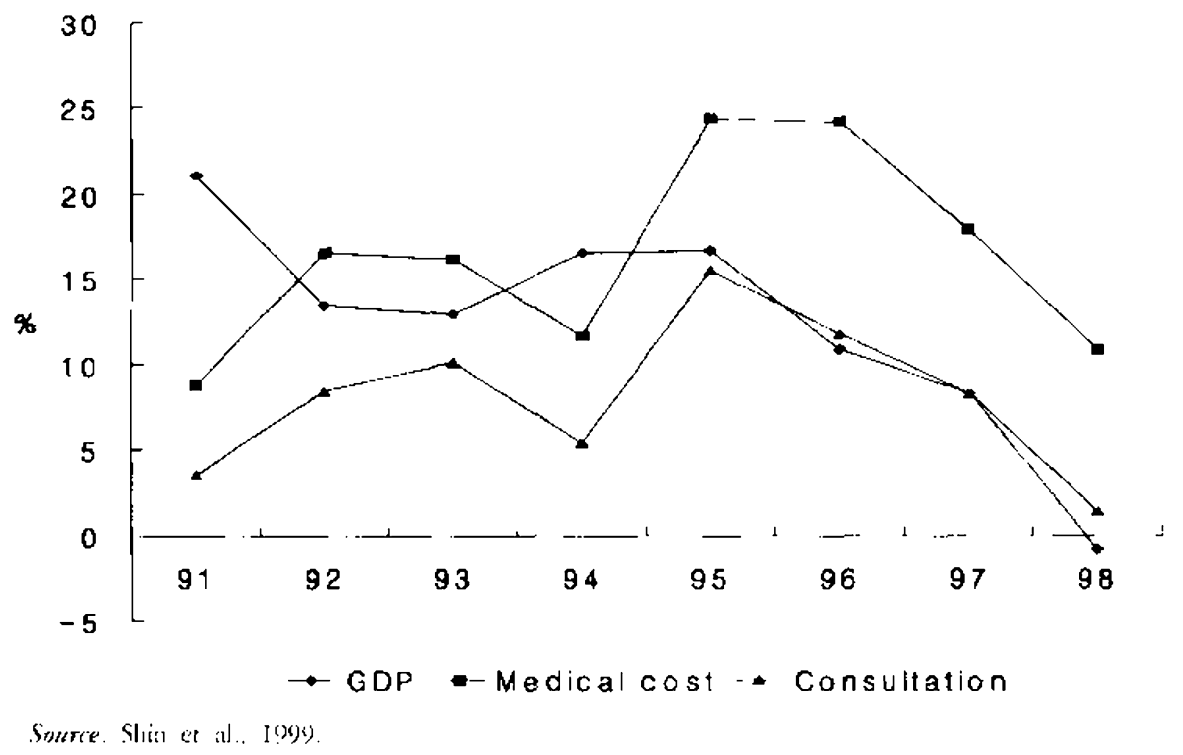

Spending on drugs and medicine on an individual level, including tradicional oriental medicine like herbs, showed the largest decline with 19.7 percent, and medical services also declined by approximately 3.1 percent. Also, as illustraced in table 6, whereas general hospitals experienced a decline in the rate of patient visits after the crisis, that of government health centers showed a dramatic increase. This fact indicates that since the crisis, duc to the average decline in income for low- and middle-income houscholds, there has been a trend in scoking modical services from relarively low-cost medical centers.



(unit: percem!

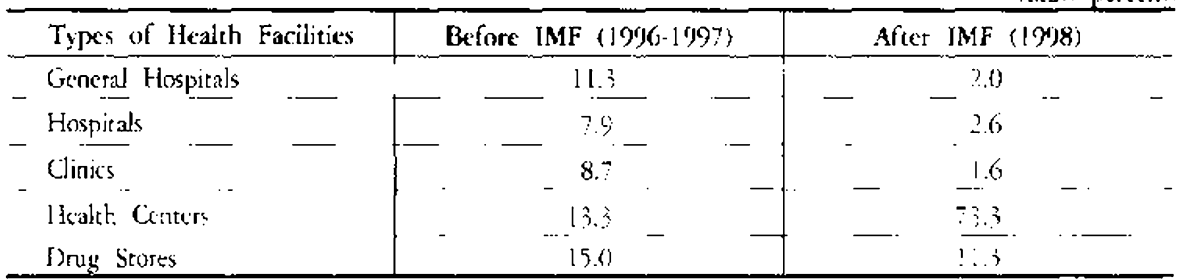

Source: Vaciunal Foderaticu of Medical Insurance, liy)

When examining household expenditure by inconse level, low-income fanilies bave 
shown an increase in their medical spending while high-incone families showed a decline by a grcarcr ratio, as presented in Table 7 . In other words, low-income families are faced with a situation where greater spending on merical gonds and services is necessary hecause of the negative health effects of the economic crisis. On the other hand, the midkle and high-income families have managed to cut their spending on so-called luxury medicinal goods and services like herbs and medical check ups, creating a general decline in medical expendicure.

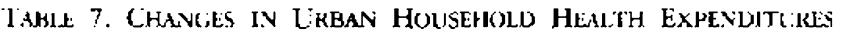

(Tur. First Half of 1997 vs ithe First Hats of 1998)

(unit: percent)

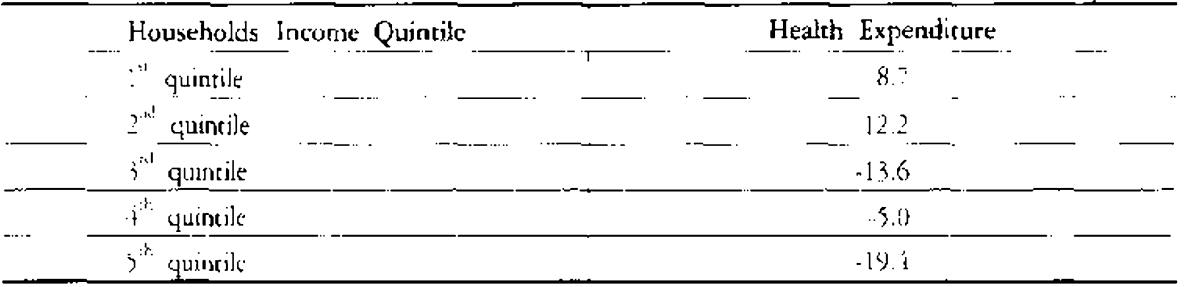

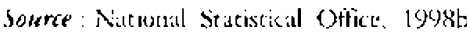

Data from the National Federation of Medical Insurance (NFMl) support the above hypothesis. There were $3,857,000$ cases for a request for health insurance payment subnitted in Iecember 1997, reaching its peak in March 1998 with 5,851,000 cases but declining slightly in September. The number of people visiting drug stores for prescription drugs also reached its highest point in March while reaching its lowest level in September (NFMI 1998). It can be speculated that those who felt burdened by medical expenses duc to unstable financial conditions settled for visits to drug stores, but since the decline in income in March, people are now even reducing their spending on incedication.

Whether the decline in medical spending has had direct negative conscquences is difficult to answer at this point in time because there are known cases in other countries where the decline in medical spending actually resulted in the decline of unnecessary medical spending. On the other hand, it would also be difficult to conclude that less spending on medical care since the crisis has had positive effects on the health behavior of the Korcan people, since most of Korca's health care system lies in the privare sector and that despite health insurance provision for its citizens, individuals rentain responsible for the bulk of their medical bill. It will be more likely to cause grearer risk to prople's health, ultimately resulting in greater expenses, if people are forced to choose low quality care or not seek help at all.

\section{Lack of Medical Resources}

The conomic crisis of 1997 first affected the exchange rates, leading to an import 
conseraint due to the devaluation of the Korean Won. The greatest constraint of all, in relation to health, was on medical resources. As soon as the cconomic crisis broke out, the Ministry of Health and Welfare (MOINW) released a report titled "IMF-Related Supply Changes in the Medical and Welfare. Sestor and Possible Policy Suggestions (translared), deading with the supply of medical resoures and foxd supplics. This report mainly deals with the problem of medical supplies made unavailable since the crisis due to the rise in the import prices of medical goods and medical supplies. There have also been numerous bankruptcies of medical centers and pharmaceutical companies trom financial difficulties (This point will be further discussed in detail later in the paper). Onc issue mertioned in the report, for example, concerns antibiotics and diagnostic reagents. In the case of antibiotics, although domestic production is possibte, becausc of an increasing number of pharmaceurical companies filing for banknuptcy, production and sales have been put on hold. But more problematic for Koreans is the use of diagnostic reagerts, 85 percent (annual worth of $\$ 75$ million of which is foreign import dependent. There is an insufficient amount stored because diagnostic reagents have in the past been traded only in small guanticies due to certain characteristics of the profuct. Compared to the level prior to the IMF bailout, imporration of diagnostic: reagents was reported to have decreased 46.2 percent in January 1998. This trend implicates that if continued, diagnustic reagents may very well run out within a month in medical institutions.

The seriousness of dwindling medical resources applic's to other medical goods as well. Materials for sanitary goods like bandages, gauze, and cotton balls are imported from councries like Pakistan and China, but in February 1998, it was reported that hospitals only have avajlable what is stored. A serious supply deficicocy was also experienced in supplies like x-ray film, surgical gloves, sutures, and dispx)sable syringes. For cxample. Korea depended annually on 850 square meters of $x$-ray film but at the time of this study, had only enough stored to last until January; surgical gloves for approxinately three months; sutures and disposable syringes for one month. Such concerns expressed by MOHW soon became a reality and the quality of medical services offered decreased in many medical facilities.

Another sexial change related to health was the string of barkruptcies in the medical sector as a result of organizational mismanagement. As reported by MOHW, smalland medium-sized hospitals, medical dinics, and pharmaccutical companies with financial problems have gone bankrupt, and brought on a chain reaction of bankruptcies in the medical sector. According to statistics released in December 1998, among 771 hospitals nationwide, 76 huspitals, which anounts to 9.9 percent, have tiled for bankiruptcy in the periox between April 1997 and March 1998. And among the 76 hospitals, 19 (25 percent) have closed down, 26 (34 percent) have undergone a clange in ownership, and 21 (28 percent) have restructured and cut the salarics of its medical staff. Seven are still operating and three have merged with other hospitals (MOHW 1998).

Most bankrupt institutions were small hospitals with less than 30 beds in the private sector. medical clinics that people usually first contact when expericocing health problems. Thesc have an average of 70 percent dependency on outside capieal and thus are nure 
vulnerable to bankruptcy. Since the Korean health care system heavily depends on the private sector, this means that accessibility to medical institutions for the pupulation has been dramatically reduced. General hospitals, which have greater linancial burdens from the rising cost of modical instrument rentals, show a decrease in the number of facilities, patients and ductors alike as shown in Table 8. Major general hospitals also face serious problems in financial management. They are managing their budget deficits by actually decreasing the supply of services offered, for example, closing down certain wings and sections in the hospital. Even hospitals that are not on the brink of bankruptcy arc expcriencing a tight budget squeeze and as a way of cutting back spending. some have laid off its workers or hircd kss qualified staff. For instance, many aid nurses are asked to work three shifts, overworking then rather than hirims new people. And when hired, they tend to be unqualified and untrained high school graduates. There have even been cases where administrarive staff were illegally trained and put to work in the ward alongside the nurses.

Tablf. 8. Ciranges in Numbers and Rates of Giniral Hospital. Fachimies, Hospital Beds, AND Doctors (1994-1998)

\begin{tabular}{|c|c|c|c|c|c|c|}
\hline General Hos & spitals & 1994 & 1995 & 1996 & 1997 & 1998 \\
\hline 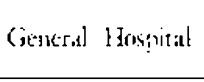 & Farilitios & $\begin{array}{c}252 \\
(4.13 !\end{array}$ & $\begin{array}{c}266 \\
5.563\end{array}$ & $\begin{array}{c}2-1 \\
(1.88)\end{array}$ & $\begin{array}{c}263 \\
(-3.32) \\
\end{array}$ & $\begin{array}{c}225 \\
(-14.12:\end{array}$ \\
\hline Hospistal Besis & & $\begin{array}{l}41,1 / 2 \\
\{1131\}\end{array}$ & $\begin{array}{l}90,865 \\
60.26\end{array}$ & 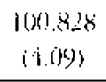 & $\begin{array}{c}100,615 \\
0(1,78)\end{array}$ & $\begin{array}{l}10:, 1:^{-} \\
(-0), 4 ? !\end{array}$ \\
\hline Daxtors & & $\begin{array}{l}21,391 \\
(6.84)\end{array}$ & $\begin{array}{l}22,683 \\
(6,04\})\end{array}$ & $\begin{array}{l}35.379 \\
(1189 !\end{array}$ & $\begin{array}{l}2(5,56) \\
(4.6(6))\end{array}$ & $\begin{array}{l}25.74) \\
(-2.88\end{array}$ \\
\hline
\end{tabular}

Source: Shin et ill, 1909 .

If medical restructuring is appropriately implemented, suct as climinating the common practice of providing high quality service only for those who can afford it co elinuinating the small private clinics providing low quality care, it could improve the quality of services offered to everybody. However, without a coherent policy to address the financial mismanagement of hospitals or a plan to improve the avalabiliry of the health care system, the harm is inflicted on those in dire need of scrvicc.

\section{POLICY IMPIICATIONS}

This paper has thus far examined the negative influences of an economic crisis on people's health. Korea has traditionally pursued accelerated economic development, putting aside distribution issues. In the process, neither the state nor its citizens bave been able to accumulate resources to fix social problems derived from the economic crisis. The situation currently faced by Korea is a situation where the IMF-guided policies 
of economic contraction have led to massive layoffs without sufficient safety nets in place. Under the circumstances, the social and welfare policies should be oriented toward cutting the vicious lirk between economic crisis, poverty, and its harmful effects on health. At least uncil the basic social welfare system is set up in Korea, the government should carry out direct economic intervention measures in employment policy and the labor market, social policies to ensure minimum health coverage, and on an individual level, social welfare programs to ease the population's adjustment process. Enhancement in the scope of a national pension scheme, normalization in the price of medical insurance, a clear division of medical and pharmaceutical sectors, integration of a medical insurance scherne, and a general improvement in the medical system ane sume of the issues that need to be addressed for a long-term effective social safecy net co emerge.

The social problem of uncmployment due to the economic crisis remains the must. serious problem in Korean society today. However, most of the imnediate government policies have not effectively addressed this particular issuc. Policies initiated by the government have heen pension schemes for the unemployed, minimization of unemployment, creation of new jobs, provision of education and retraining, and enforcement of employer and employee networks for the unemployed.

In efforts to maintain the health and quality of life of the unemployed, the provision of a cerrain lcvel of financial security is a minimal requirement. The government took the mest direct form of intervention by increasing unemployment insurance benefits for those working at a workplace of five or more workers. The scofe of unemployment benefits has increased 50 percent and the time frame of support has also bxen extended. However, workers working at a workplace with more than five workers only amount to 32.3 percent of the whole labor force. Also, the unemployment benefits for receivers like farmers and street venders are eligible from October 1998, but in practice since one has to be insured for at least six months to enjoy the benefics, it was not to be made available until March 19\%9. 'Those most affected by the economic crisis, temporary workers with low wages, are tort even eligible for uncmployment insurance benefits for some time (Pascha and Kwon 1998). Social safety nets must be designed to encompass such vulnerable groups of people and provide immediate assistance. Prolonged unemployment will not only breed negative economic consequences, but also social instability ranging from an increase in crime to an increase in family disintegration. Hence, policies that provide a minimal assistance of survival to those in need must become a prionity in minimizing the soxial impact of the economic crisis.

As for government health policy, a direct approach was taken to alleviate the problem of the lack of medical supplies. In order to relieve some of the financial burdens faced by the health sector, MOHW initiated shorr-tern measurcs by temporarily widening the range of Medicaid recipients, allowing mure time for payments, making loans available for payments, and so forth. However, such measures are limited to a small number of people, failing to provide benefits for the population at large. Hence, in a situation of mass unemployment, the scope of eligibility for medical insurance must be cemporarily extended at large, which will help mediate the shock of unemployment for families 
and individuals affected.

In addition, taking into account the fact that family networks have historically played the role of a social safecy net in Korea, policies should take an inclusive group appruach, where whole families with unemployed members are provided assistance, wot just the individuals. One suggestion would be for various social or religious organizations to provide professional consultation services to families in nced, as well as welfare education lecrures where people can learn to deal with stress without resorting to self-abuse.

However, although such services work as temporary selicf, for health and quality of life to be enhanced, a systematic social safety nee is required. For a long-eerm social protection system to be established, drastic reform in the current health care system is neederd.

The current national halth insurance system only covers 25 percent of the roral medical bill such as Medicaid. In other words, the low-income strata and unemployed are left to take responsibility for their medical bills, making it difficult to scek medical resources when necessary. Although the government implemented another policy to extend the eligibility for Medicaid to the unemployed and their families, the situation is worse for the homeless, with only 20 percent of the homeless population medically insured. Ever prior to the crisis, there were many instances where the medically insured were charged a similar rate with ochers. Hence, not only werc the uninsured homeless inadequately looked after, but those in the low-income strata were no better off. In times of econmic crisis, the Modicaid system is clearly failing to meet the true needs of the people (H. Kim 1998). It is urgent that a substantial portion of government reserves should be dedicated to broadening the sope of medical insurance service to encompass both low-income familics and the homeless.

This assessment can be applied to the general health insurance system, which covers all Korcan citizens. In reality, the individual share is large and since some of the most common services are not applicable for insurance coverage, the current health insurance system is considered to be inadequate and pegged with many problems. The confusion and conflict illustrated by recent debates over the divisive roles between doctors and pharmacists, as well as the integration of health insurance socieries and health insurance corporations, are largely due to the government's unwillingness to share the financial burden, leaving it to the health service providers and their consumers. Hence, in order to overcome the shortcomings of the health insurance system, the government must work towards acquiring a sufficient budget to lower individual burden and find a means by which the central or regional government can fully support their health expenses.

Reforms in social services, such as unemployment policy, family welfare, and health insurance, may noc appear to be directly related to the currene econonic crisis and thus they are not given a high priority in the overall reform policy. However, the impurtance of these social welfare policies must not be underestimated, for they concern the cost-effectiveness of soxial services, which is in turn directly related to the efficiency of the public sector. For Korea to resume its patt of economic growth, social stability must be attained by avoiding band-aid solutions and designing approprate 
social policies to adeciuately meet the needs of the overall population on a long-term basis. The current economic restructuring may pull the economy out of the crisis, but it is these long-term social reforms that will allow the economy to resunke and sustain its development path after the initial recovery. Like the long-term, inclusive social welfare system designed by the Innited States at the time of the Great Dxprcssion and England's Beverage Report after World War II, Korea should take this opportunity to create a framework for a social welfare system that will promote its development in the most substancive senst.

\section{REFERENCES}

Breakey, W.R, Fischer, P.J., Kramer, M., Nestadt, G., Romano, A., Ross, A., Royall, R.M. and Stine, O.C 1989. "Health and Mental Health Problems of Homeless Men and Women in Baltimore". JAMA 262 (10): 1352-57.

Brenner, M.H. 1987a. "Economic lnstability, Lnemployment Kates, Behavioral Risks, and Murtality Rates in Scotland, 1952-1983." Intermational Joumal of Health Senices 17 (3): 175-87. . 1987b. "Economic Change, Alcohol Consumption and Heart Disease Mortality in Nine Industrialized Countries." Social Scienot and Medicine 25 (2): 119-32.

1987c. "Relations of Economic Change to Swedish l lealth and Sicial Well-Being, 1950-80." Srical Sience and Medicine 25 (2): 183-95.

Catalano, RD. Doodley, G. Wilson and R. Hough. 1993. "Job Loss and Alcohol Abuse: A Test Lising Data from the Epidemiologic Catchment Area Project." Jgumal of Health and Sxial Bebation 34: 215-25.

Cho, H.J. 1998. "The Health of the Uncmployed and Social Safery Vet (in Korcari)." Unipublished paper presented at the Meeting of the Association of Humanistic Doctors.

Chni, B.Y. 19)8. "The Prevalence and Management of Hepatitis A in Korea." Pracedings of the Korean Litis Association Meting. Seoul.

Chosunllbo, Ficbruary 20, 14)

Dooley, D. and Catalano, R 1988. "Recent Rescarch on the Psychological Effects of Incmployment." Journal of Sarial lisuer 44 (4): 1-12.

Fryer, D.M. and Payne, RL 1986. "Being Unemployed: A Review of the Literature on the Psychological Experience of Unemployment." International Review of Industriat and Organizational Psycholingy. exts. C.L. Couper and I. Robertson. London: Wiley.

Goldbladr, P. I (x) "Mortality and Alternative Classification." In Lomgitulinal Study 1971-1081: Mrnaliny and Sacial Organization, ed. P. Goldbladt, OPCS. IS Series, No.6, HMSO, London.

Hammer, 'I. 1992. "Unemployment and Lise of Drug and Alcohol among Young Peuple: A Longitudinal Study in the General Population." British Joumal of Addicsion 87 (11): $1571-81$.

Iversen, L. and Sabro, S. 1988. "Psychological Wee-being among Unemployed and Employed People After a Company Closedown: A Longitudinal Study." Joumut of Sricial Issuter 44 (4): $141-52$.

Jahudit, M. 1988. "Ecomomic Recession and Mental Health: Sume Conceptual Issues." Journtal of Sincal Issuei $\{14$ (4): $13-23$.

Kim, D.H. 1998. "Unemployment: Structure and Behavior of Stress and Mental Health. Health and Sicial Science (in Korean) 3: 45-66. 
Kim, 14.5. I998. "The Limits of the Current Unemploynent Policy and the Counser-Tasks." Health and Srial Scronse (in Korean) 3: 103-2/.

Kim, M.U. and Nho, Y.H. 19)8. "A Study on the Mental, Cognitive, Physical Reactions and Coping Behavior of the Unemployed." Proxedings of Anmual Kontan Ps\}baligial Ariziation Mecting (in Korean). Stoul.

Korca Institute of Hospital Managernent. 1998. Statistical Report on 1 lealth Expenditures, Serul, Koreit.

Korea Labor Institute. 1998. "Iabor Marker Policy and Inemployment in 19oy." Priectilings of Prilic Fomm. Linpublished Manuscript.

Lee, M.S. 1998. "Lnemployment and Family Disorganization in the Cintext of Current Leononic Crisis of Korea." Halth and Srial Sciente (in Korean) 3: 83-102.


P37ibulgrial Asirciation Meeting (in Korean). Scoul.

Lee, H.K., Yoon. S.Y. and Chung, H.K. 1998. "A Comparative Study on the Children

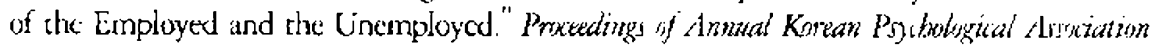
Meeting (in Korean). Seoul.

lee, J.H. and Kim, D.I. 1998. "Grisis and Reforms in Korea's Lator Market." Korea Development Institure working paper (unpublished).

L.jem, R and Liem, J.H. 1988. "Psychological Effects of Unemployment on Workers and Their Farrilies." Jownal of Serial lsowes $1 / 4$ (1): 87-105.

Ijerr, R and Raymats, P. 1982. "Health and Social Costs of Lnemployment: Rescarch and Policy Considerations." American Psychologist 3? (10): 111 (6-2).

McLoyd, V.C. 1990. "The Impact of Economic Hardship on Black Families and Children: Psychological Distress, Parenting, and Socioemotional Development." Child Detwopment 61: $311-16$.

Mtinistry of Economy and Finance. 1998. "Policy Intcrvention for the Unemployment in 1998." Report presented to the Committee of Economic: Crisis. Seoul.

Ministry of Health and Welfare. 19)8. Annual Statistical Repart. Seoul.

Moxn, 13. 1979. "Fannily Inquacts of the 1975 Recession: Duration of Employnkent." Mlamiage and Family is (Ang): $561-7$ ?

_. 1483. "Linemployment, Public Policy, and Familics: Forecasts tor the 1\%80): "Hamuage and Famil) 8 (Sep): $751-60$.

Moliar, J.M. Rath, W.R and Klein, T.P. 19)0 "Constantly Compromised: The Impact of H Humelessness on Children." Joumal of Soxial issmes 16 (4): $1(x)-24$.

Narional Federation of Medical Insurance. 1998. Medical lnsurance Statistics. Sotoul. 1999. "An Analysis of the Changes in Health Expenditures after liconomic Crisis." Sockal Secmen Vol. 131 (April): 26-X).

National Statistical Office. 1998a. Annual Report on tle bionomically Active Population. Sxroul.

1998b. Annual Report on the Family Income and Fixpenditure Survey. Serul.

Pascha, W. and Kwon, S.W. 1998. "Globalization, Economic Crisis and Sucial Disintegration in Korea." The Neceisity of Sacial Stabilization Policiej. ed. Nord-Sued Aktudl. Forthoming. Rabkin, J G. and Streuning, E.L. 1976. "Life Events, Stress, and Illness." Sikethe 194: 1013-20.

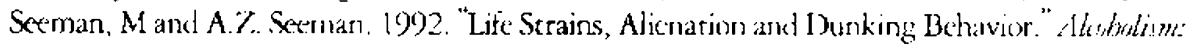
Climal and Faperimental Researb 16 (2): 19)-205.

Shin, Y.S. Slin, H.W., and Stin, J.K. 1999. The Anlaysis of Health Care Ixpenditures and Polry Options. 
Shun, Young Chul, Shin, l lyun Woong, and Shin, Jong Gakk. 1949. "The Factors of lncreasing Medical Insurance Foc and Policy Issues." Annual Rejort 99-03. Korea Instituce of Heialti and Sxcial Affairs.

Suh, M.G. 1998. Detelopmental Transiomation in Soutb Kerea: From Siatt-Sponsored Grinuth to the Quest for Quality of Lift. Westport: Praeger.

Suuch, S.J., 1985. "Economic Conditions and the Diverce Ratc: A Tumcs-serics Analysts of the Postwar Inited Stares." Marriage and Family 47 (Feb.): 31-11.

Svensson, P. 1987. "International Soxial and Health Policies to Prevent Il] Health in the Lnemployed: The World Health Organization Perspective." Srizal Sitente and Mudicint 25 (2): $201-4$

Whang, S.H., Y(x), H.J. and Han, O. 1998. "The Effects of the Fxonomic Stress on the Mental Status of the Unemployed." Procedings of Anmeal Korean Psychalogical Association Metting (in Korean). Sxoul.

Wright, J.D. 1990. "Poor People, Poor Health: "The Health Status of the Homeless." Joumal of Sicial Issies 40 (4): 49-64.

Y(o, J.S. 1998. "The Sratus of Soxial Safety .Ne: In Respomse to the Mass Lincmplaymentr." Jaumat of Currem lssues and Perspectives (in Korean) 3: 25-37. 